\title{
Information System of Yadnya Ceremony on Android-Based
}

\author{
Oka Sudana, A.A.K ${ }^{1}$, Sukarsa, I Made ${ }^{2}$ and Wahyu Saputra, I Made ${ }^{3}$ \\ ${ }^{1,2,3}$ Department of Information Technology, Udayana University, Bali, 80119 \\ agungokas@hotmail.com,e_arsa@yahoo.com, \\ madewahyusaputra@yahoo.com
}

\begin{abstract}
Implementation of very large religious ceremonies in Bali demanded Hindus to be able to understand things related to Yadnya ceremony. One of the reasons why people are reluctant to participate in the Yadnya ceremony is because they does not know how to execute the ceremony. A way that can be taken is to design and make a model of the system that presented the Yadnya ceremony through Android-based information systems. The system will provide information related to activities such as execution time of Yadnya ceremony, implementation procedures, pemuput, place of ceremony, video, and images of the ceremony. Users will obtain data or information by accessing the application from the server system.
\end{abstract}

Keywords: Android, Information System, Tree Diagram, Yadnya Ceremony

\section{Introduction}

Bali Cultural Tourism is one of Bali's most interesting for tourists. Yadnya ceremony in Bali is one part of the Balinese culture that must be preserved. Yadnya ceremony in Bali covering various aspects that support the implementation of the rituals for the Hindu community in Bali. Yadnya ceremony and ulam Bebantenan is one of the medium to implement a core part of Hindu ritual [1].

Implementation of Yadnya ceremony is a spiritual guidance to appreciate the source of happiness of life from God, man and nature and its contents [2]. The existence of Yadnya ceremony is important to be maintained, one way to maintain Yadnya ceremony is by introducing it to the younger generation. The introduction can be done with a practical and efficient manner utilizing the technological advances which is developed at this time.

The most popular and growing technology recently is mobile device, or better known as smartphones. This technology is very popular because of its presence which has a variety of interesting features in it. These features include multimedia, games, until the Internet network. The Internet network feature is the most popular one in community because of the ability that Internet can provide and the ease to obtain information.

The existence of technology then will be combined with Balinese culture which is associated with the Yadnya ceremony, will give a good lesson for the Hindus in Bali. Efforts to do here is to design an application that can provide relevant information about Yadnya ceremony activities. The basic concept of the application is an information system of Yadnya ceremony based on Android in order to make interested to public to use it, other than that the Android-based applications are very well known by the public at large.

Yadnya ceremony application is an information system that provides information about the Yadnya ceremony. The purpose of the system designed is to make people easily obtain information about the Yadnya ceremony.

\section{Research Methods}

The working stage of this application is through several stages or methods outlined in a research plot. The flow of research is used as a reference in the working stage of the 
application in order to make sure the application will be done according to schedule. Some of the grooves are made to work on the application of information system is illustrated in Figure 1 in the following flow chart.

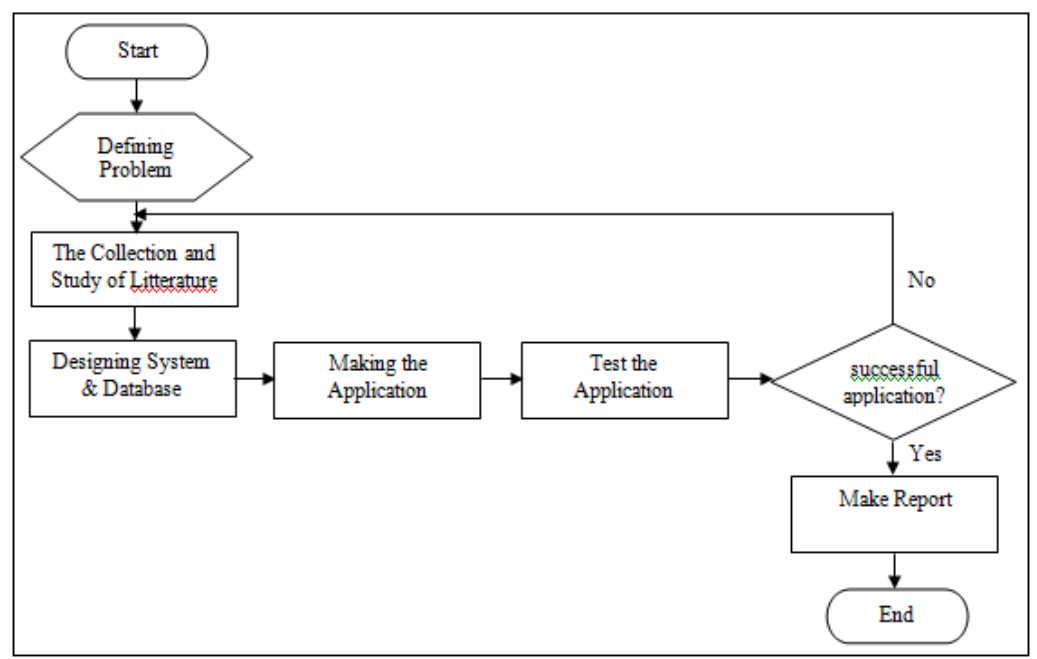

Figure 1. Research Diagram Flow

Figure 1 illustrates the flow of research that consists of several stages, include:

a. Defining the problem, is the initial step before the study were defining the issues raised in the study.

b. The collection and study of literature, collection of data and literature related to the manufacture of Application Systems.

c. Designing systems and databases, applications include systems design phase, a database, as well as interface design. The design of the application must have a mature concept that will facilitate the making of the application stage.

d. Making the application, where the application developed for mobile which is based with Java as a programming language and MySQL as the database.

e. Test the application, application testing and analysis as well as documentation of the results of such testing. Errors contained in the system will then be repaired until no more errors are found.

f. Make reports, preparation of reports which includes the overall research that has been done. Reports are made to explain the process of making the application that starts from background processing application, workflow processing application, a general description of the application until the final stage of completion of the application. This report is used as written evidence of the process of the application that will be used as a literature review for the next research work.

\section{Modeling System}

Modeling the system was conducted to determine the relationship between ritual ceremony with the other one by using the Tree diagrams. Tree diagram is a method for modeling the system. This structure has specific characteristics and typically used to describe the hierarchy of elements relationship. [3]

Tree modeling can also provide the understanding about the system that are made so it will helps in the process of database design and application program. In general, a Yadnya ceremony will have the following properties:

a. Yadnya group, is to determine the group of the ceremony.

b. Description, is to explanation the Yadnya ceremony.

c. Execution time, is the time or day when the Yadnya ceremony being held. 
d. Levels of ceremony, which is a level of ceremony Uttama, Madya, Kanista or common level.

Tree were rooted at the level of the ceremony, which contains about Pemuput, place of the ceremony, the implementation procedures, means of ceremony, video, and pictures of the ceremony. Pemuput, place of ceremony, the implementation procedures, means of ceremony, video and pictures are placed after the degree of the ceremony because the same ceremony might have different levels of pemuput, place of ceremony, implementation procedures, means of ceremony, video and pictures of different ceremonies, as in Figure 2.

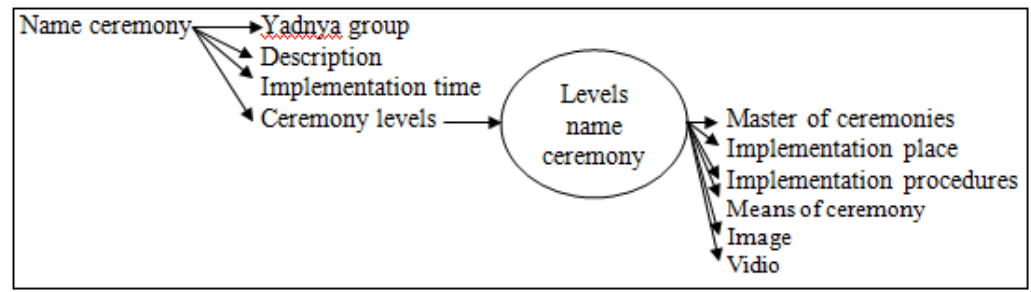

Figure 2. General Modeling of Yadnya Ceremony

The circled property names in Figure 2 shows that the property can have more than one value. An example is the degree ceremony for the property name that can have a value of Uttama, Madya, Kanista or Common. Examples of the application of this model can be seen in Figure 3, namely modeling for Tiga Bulan ceremony.

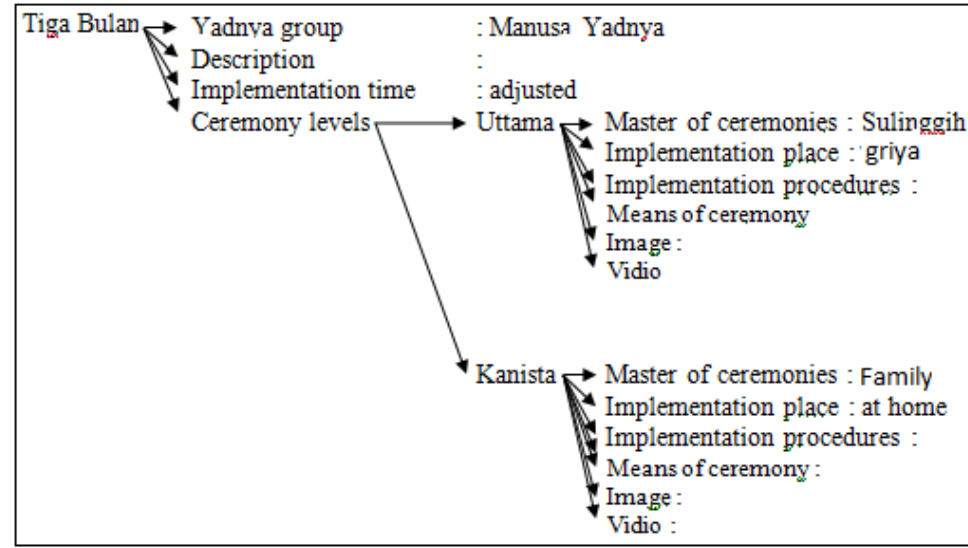

Figure 3. General Modeling Tiga Bulan Ceremony

Figure 3 shows an example of modeling that name is Tiga Bulan ceremony. This ceremony has properties such as:

a. Yadnya group, which includes Manusa Yadnya;

b. Description, which describes the ceremony in general;

c. Execution time, which is when the baby is 105 days old;

d. Levels of ceremony.

Tiga Bulan ceremony has two tiers ceremony so the tree will have two branches, namely that leads to a level that Uttama and Kanista. Next on the level name followed by a subtree named place, pemuput, procedures, tools, videos and pictures of the ceremony.

\section{Results and Discussion}

General overview and discussion of related systems on the client side and the server as well as the results obtained in the studies discussed in this section. 


\subsection{General Description of the System}

The system consists of two sides that can be interconnected, with the help of the web and Internet network services to manage the database on the client application. Web service is defined as an interface that describes a set of operations that can be accessed through the Internet in the form of XML messages (eXtensible Markup Language). Web services provide a standard communication between different software applications and can run as a platform and framework [4].

Application of Yadnya ceremony used as a media introduction of the types of ceremonies in Bali to the general public, especially the younger generation. In addition, this application also aims to participate in the effort to preserve the arts of Bali. This application is expected to provide information about Yadnya ceremony in Bali.

Information system of Yadnya ceremony consists of administrator and guest. Information systems administrator accessed via a web browser, while guest is accessible via Android Smartphone devices. General overview of the application of Yadnya ceremony information system can be seen in Figure 4.

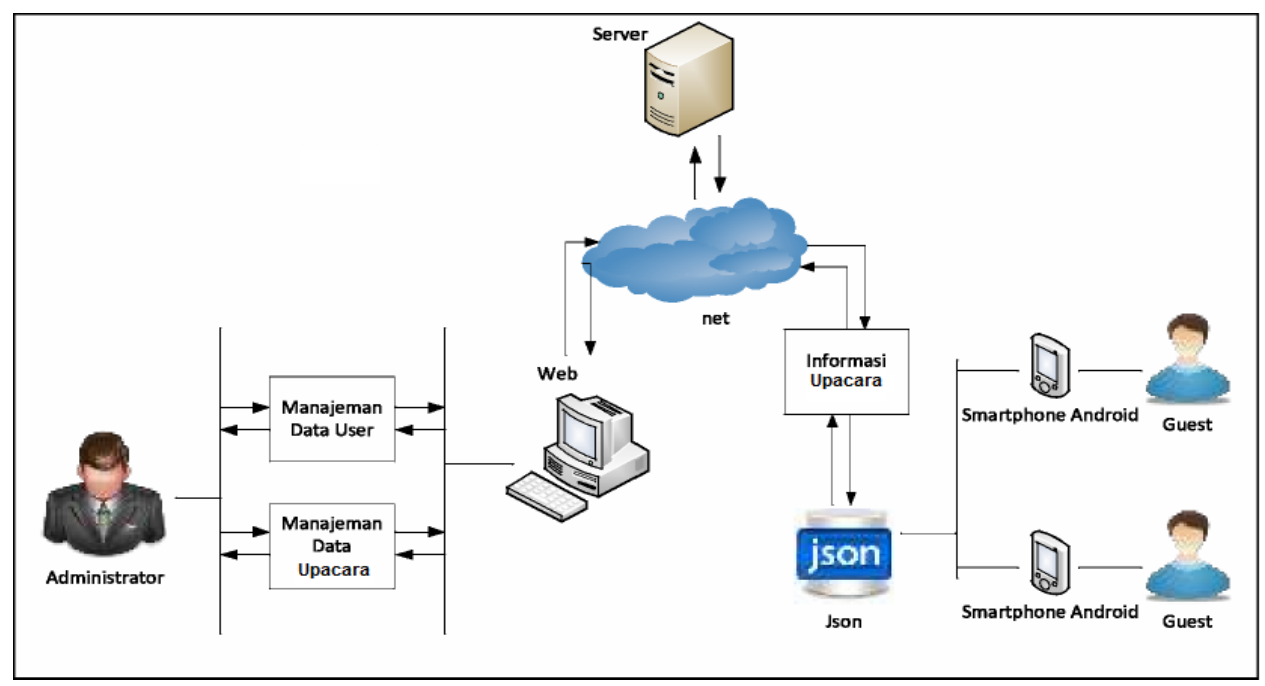

Figure 4. Overview of Yadnya Ceremony Application

Figure 3.2 above shows how the user or guest in obtaining the information. First of all, a user will make a request (request for information) via the Android Smartphone and Android Smartphone devices will then send the request to the Internet to get data from the database server. Between the application and the database server takes a PHP file with the JSON data format to accommodate the results of a database query which will then be parsed and displayed in the Android Smartphone devices.

The information displayed to user or guest is entered to the server by administrator. PHP file with the JSON format taking query results from the database server and displayed in the Android smartphone devices [5]. Administrator will input data about Yadnya ceremony through the administrator page and then the data will be uploaded to the server through the Internet.

\subsection{Application Display on Client Side}

System on the client side will formed as an Android application. Through this application the client can obtain the needed information. Application on the client side, shows information about the Yadnya ceremony that contains data such as description, level, execution time, place, pemuput, implementation procedures, tools, and drawing ceremony. Clients gain access to application data by using an Internet connection to the server system. Initially the client choose the data wanted to display, then the server sends the selected data, 
the server data will display in form of descriptions, levels, time of execution, the execution, peтириt, procedures, facilities, and drawing ceremony.

\begin{tabular}{|l|l|l|}
\hline Bis Upacara Yadnya & Genymotion for personal use - Sony Xperia Z - 4.2.2 - API 17 - 10... \\
\hline DEWA YADNYA & RSI YADNYA \\
\hline Search... & MANUSA YADNYA \\
\hline Purnama/Tilem & \\
\hline Soma Ribek & \\
\hline Sabuh Mas & \\
\hline Pagerwesi & \\
\hline Tumpek Landep & \\
\hline Minggu Umanis Ukir & \\
\hline Selasa Kliwon Kulantir & \\
\hline Tumpek Penguduh & \\
\hline Penampahan Galungan & \\
\hline Galungan & \\
\hline
\end{tabular}

Figure 5. First Page

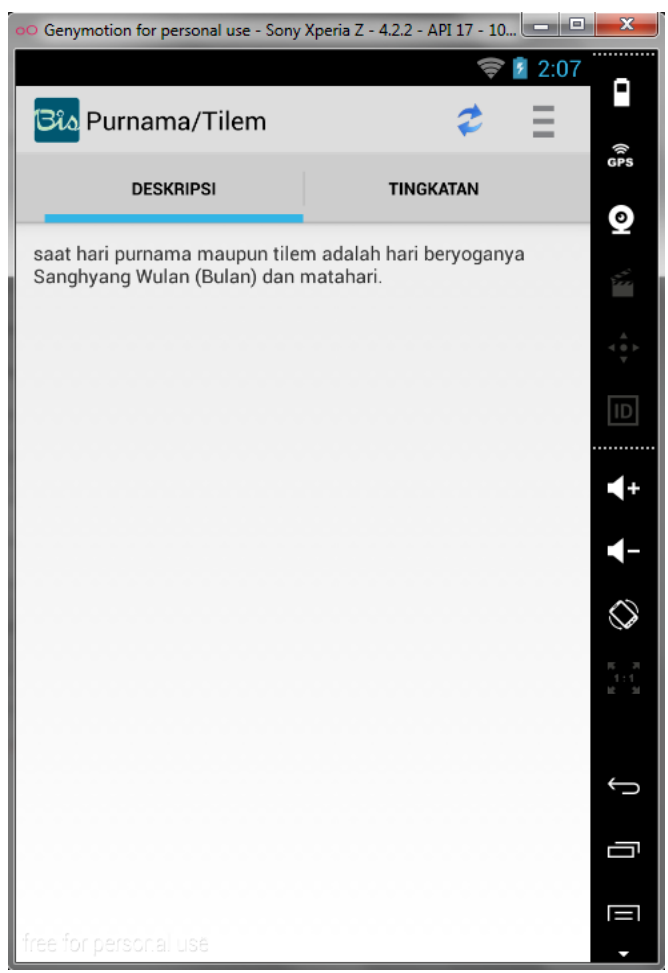

Figure 6. Ceremony Page 
International Journal of Hybrid Information Technology

Vol. 7, No. 6 (2014)

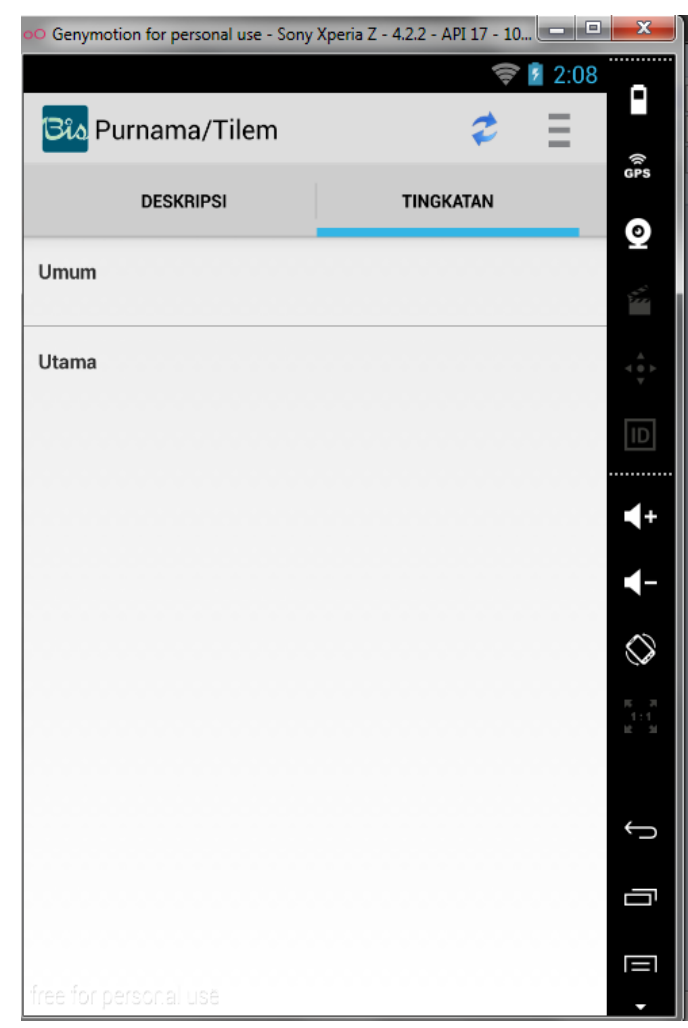

Figure 7. Level Page

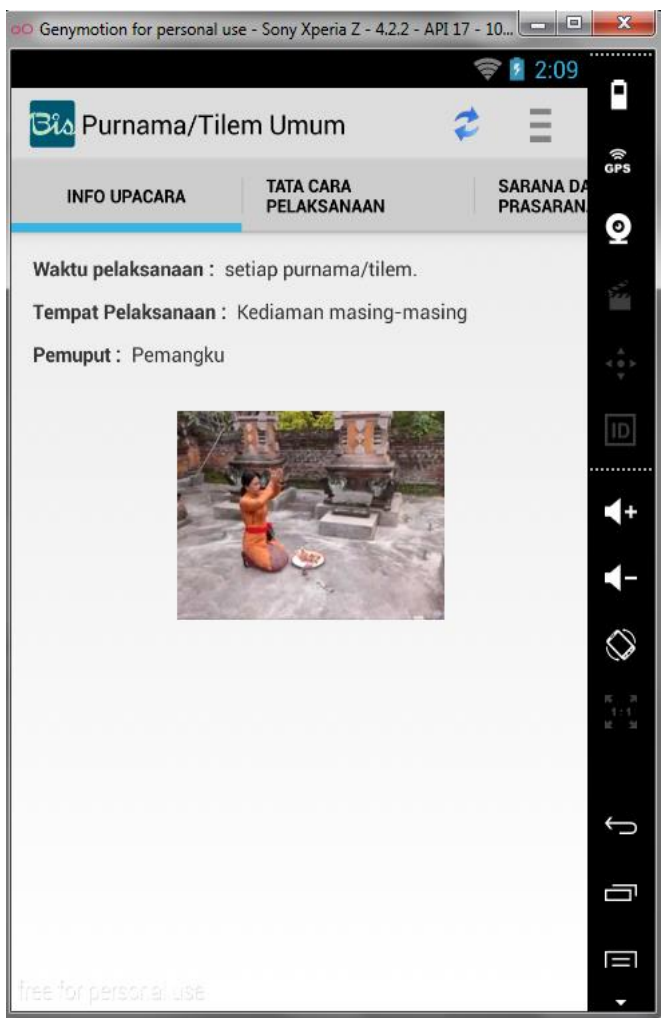

Figure 8. Ceremony Details Page 


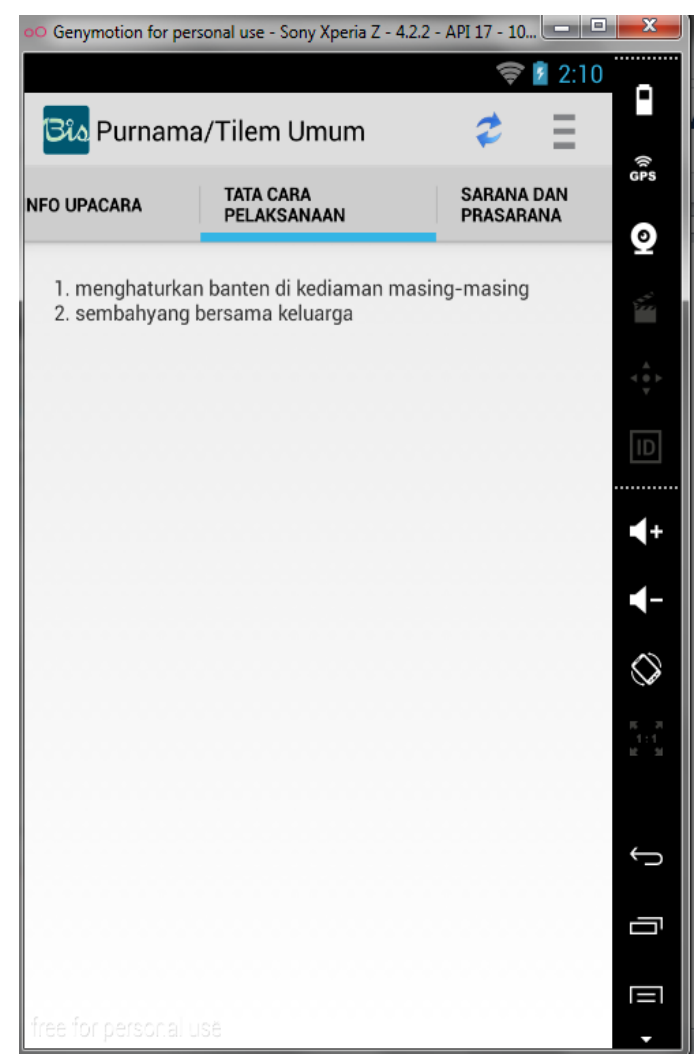

Figure 9. Procedure Page

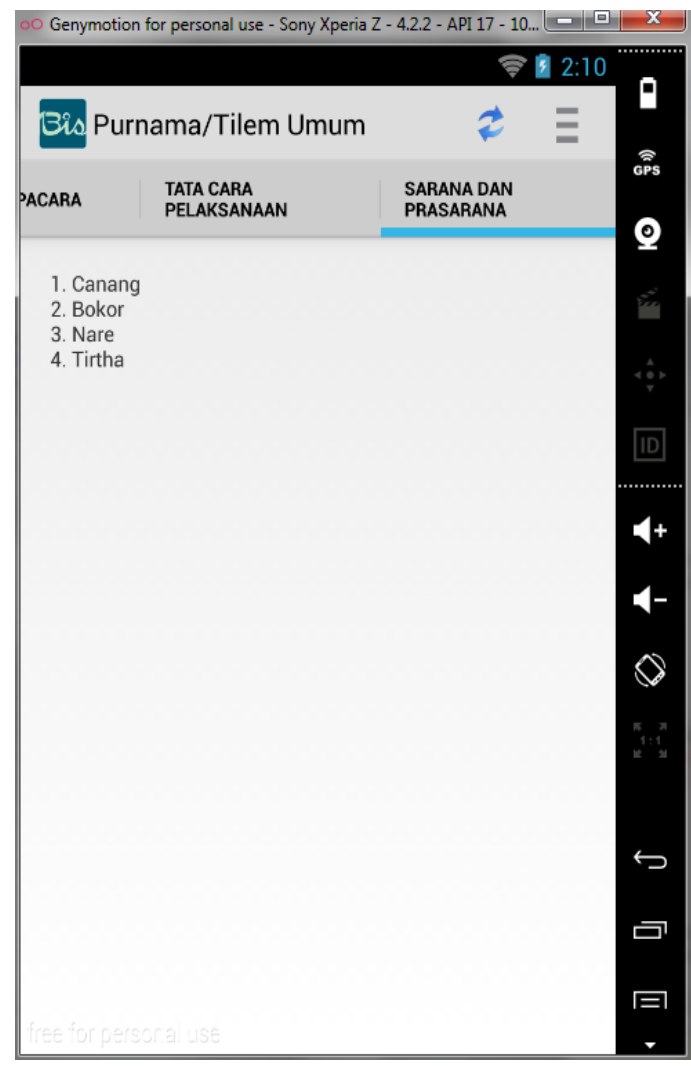

Figure 10. Ceremony Facilities Page 


\subsection{Application Display on Server Side}

The administrator page is built in web-based applications. This application can be accessed in browser. The administrator page is to managing the database. The database system is essential to the development of the system [6]. The data entered on the page will be stored in a database administrator on the server. Through this application administrator can perform management on the database. They can then take additional data as in Figure 6.

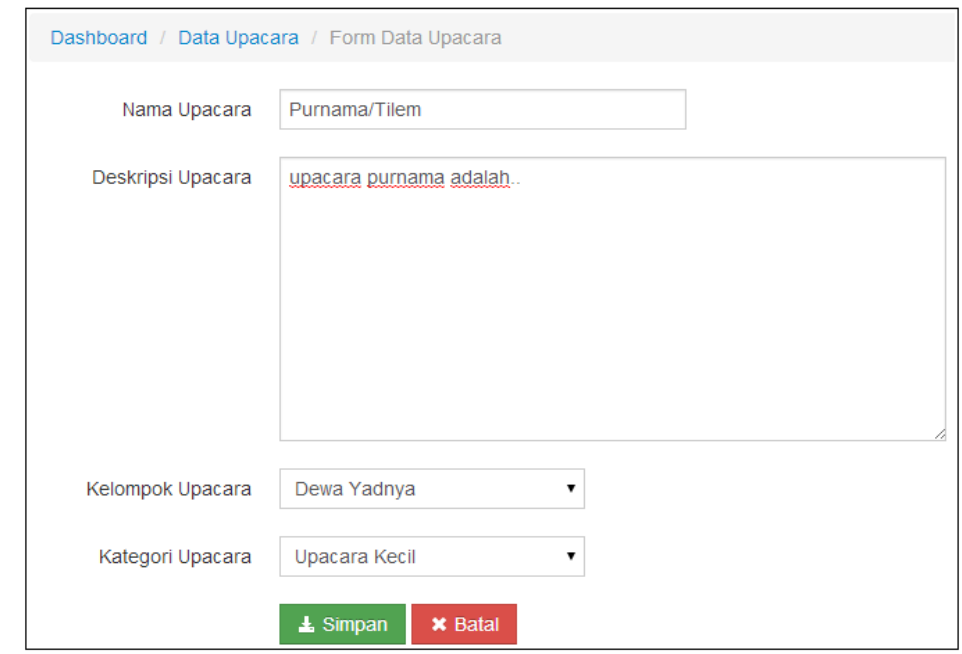

Figure 11. Display of Data Adding Form

If the data in Figure 6 is saved, it will be displayed at a ceremony as part of the list seen in Figure 7.

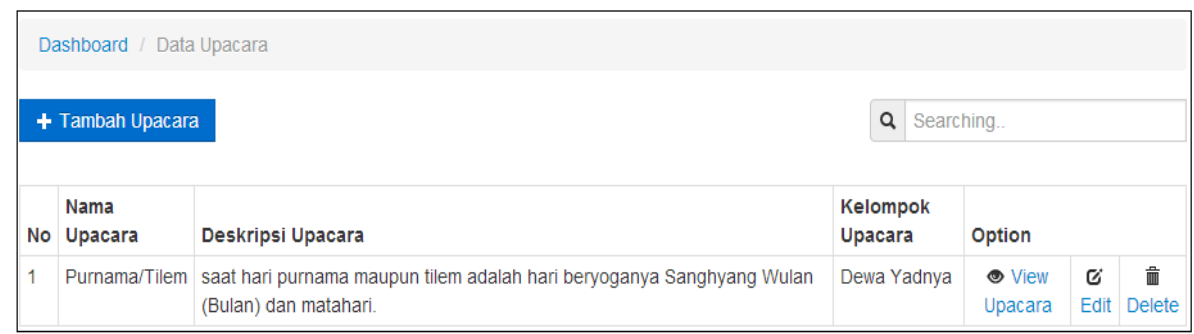

Figure 12. Display of Ceremonial List

Administrator can add the data in more detail by selecting the ceremony view. Data can be added such as execution time, place, pemuput, procedures, facilities, and ceremonial images as shown in Figure 8.

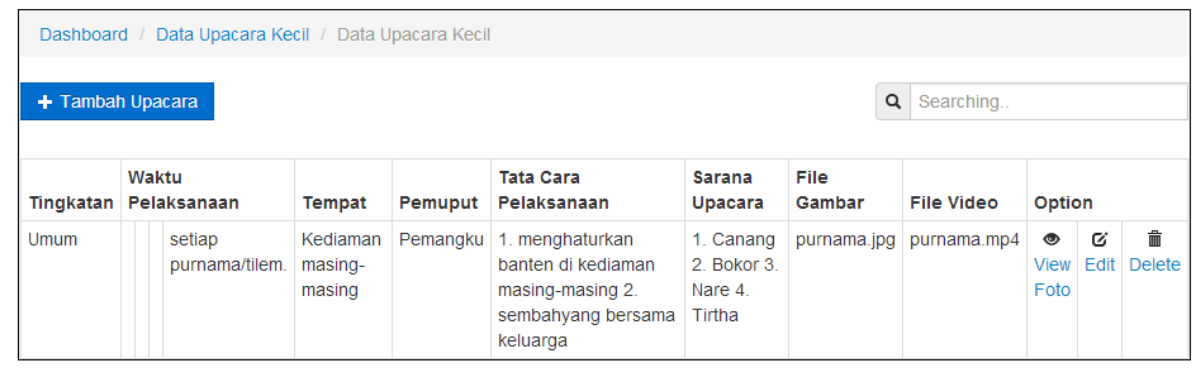

Figure 13. Display of Data Adding in Detail 


\section{Conclusion}

The conclusion that can be drawn from the information systems of Yadnya ceremony application is as follows:

a.Yadnya ceremony can be made by a standard model that has properties that can be used by all ceremony as group, description, time of execution, the execution, ordinances, pemuput, levels, graphics, and video of ceremony.

b. The tree diagram can be used to modeling the ceremony, because an ordinance can have multiple sub-level with a certain degree of depth.

c.The application made with Android-based, so that users will be able to access the information from anywhere through the Internet.

d.Users with administrator authority can access the database processing so that the data contained in the database will grow and be able to help provide more information to many other user.

\section{Acknowledgements}

Thank you spoken to the whole community of the Department of Information Technology that has helped in the success of this research, and thank you also spoken to colleagues who have made significant ideas, input, and solutions in the completion of this research. All given assistance is very helpful in the success of the research of application of Yadnya ceremony information system.

\section{References}

[1] O. Sudana, A. Agung K. Sistem Informasi Bebantenan Dalam Kaitannya dengan Upacara Yadnya. Jurnal Teknologi Elektro, ISSN: 1693-1951. Jimbaran : UNUD, 2009.

[2] Putu Darma, I Dewa. Upacara agama hindu di bali dalam perspektif pendidikan konversi tumbuhan. Jurnal Pengabdian Masyarakat, ISSN: 1412-0925. Jimbaran : UNUD, 2008.

[3] Oka Sudana, Anak Agung K. Tree Structure Implementation in Web Base E-Bebantenan. Journal of CSTID. Jimbaran : UNUD, 2009.

[4] Jogiyanto HM. Analisis dan Desain Sistem Informasi: Pendekatan Terstruktur Teori dan Praktik Aplikasi Bisnis. Yogyakarta: Andi Offset, 2005.

[5] Dunlu PENG, Lidong CAO, and Wenjie XU. "Using JSON for Data Exchanging in Web Service Applications," Journal of Cumputational Information System 7:16. Desember 2011.

[6] Joseph M. Hellerstein, Michael Stonebraker, and James Hamilton. "Architecture of a Database System". Foundations and Trends in Database. Vol. 1 No. 2 (2007) 141-259.

\section{Author}

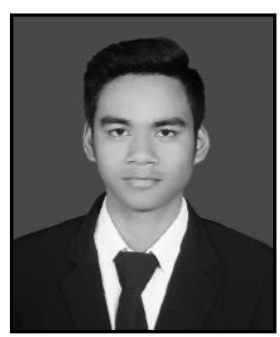

Name : I Made Wahyu Saputra

State: Indonesia

Place, Date of birth: Denpasar, 17 October 1992

Institute: Universitas Udayana 
International Journal of Hybrid Information Technology

Vol. 7, No. 6 (2014) 